\title{
EFFECTS OF EARTHQUAKES IN POSTOJNA CAVE SYSTEM
}

\section{UČINKI POTRESOV V POSTOJNSKEM JAMSKEM SISTEMU}

\author{
Stanka ŠEBELA ${ }^{1}$
}

\begin{abstract}
UDC 550.34:551.44(497.4 Postojna)

Stanka Šebela: Effects of earthquakes in Postojna cave system Regarding the studied historic references there are sufficient proofs that during the 1st January 1926 earthquake $(M=5.6)$ in Postojna cave system (Sala del Candore or Pralnica) a stalagmite column of 1 meter in diameter collapsed. This is a not so common event in karst caves and took place due to the close vicinity of the epicentre located at the SE end of Idrija Fault or at the Javorniki Mountain. During earthquakes in karst caves brontides are generally heard, but ground movement is rarely felt. Only strong and close earthquakes can be felt as ground shaking or waving inside the caves also, with some possible collapses as well.

Keywords: earthquakes, Postojna cave system, Slovenia.
\end{abstract}

\author{
Izvleček \\ UDK 550.34:551.44(497.4 Postojna) \\ Stanka Šebela: Učinki potresov v Postojnskem jamskem siste- \\ $m u$
}

Glede na proučevane zgodovinske vire obstaja dovolj dokazov, da se je med potresom 1. januarja $1926(\mathrm{M}=5.6)$ v Postojnskem jamskem sistemu (Sala del Candore ali Pralnica) zrušil stalagmitni steber, ki je meril 1 meter v premeru. To je redek pojav v kraških jamah, ki se je zgodil zaradi bližine epicentra, ki je lociran v JV konec Idrijskega preloma oziroma v Javornike. Med potresi se v kraških jamah večinoma slišijo brontidi, premikanje tal pa je redko. Le močni in bližnji potresi se lahko čutijo kot tresenje ali valovanje tal v kraških jamah, možni pa so tudi posamezni podori.

Ključne besede: potresi, Postojnski jamski sistem, Slovenija.

\section{INTRODUCTION}

Since 2009 Karst Research Institute ZRC SAZU has a role of cave guardian for Postojna and Predjama cave systems. In 2009 Postojna cave system received almost 500,000 visitors. The duty of the cave guardian is to perform expert control and recommendations for sustainable management of natural values, to formulate suitable directives for sustainable use of natural values, and to perform the climatic and biologic monitoring of both cave systems. Beside this the cave guardian collects data on old and current scientific and other researches of the cave system (Šebela 2010).
Since 2004 in Postojna cave system regular monitoring of 3D micro-displacements detected by TM 71 extensometers is organized (Gosar et al. 2007; Šebela 2005, 2008; Šebela \& Gosar 2005; Šebela et al. 2005, 2008, 2009; Gosar et al. 2009). In this sense the study to collect information and publish reports on stability of cave passages and cave decorations during earthquakes was accomplished and is presented in this paper. The study is focused into the evaluation of historical sources about reported stalagmite collapse in Postojna cave system during the 1926 earthquake.

${ }^{1}$ Karst Research Institute at ZRC SAZU, Titov trg 2, 6230 Postojna, Slovenia, e-mail: sebela@zrc-sazu.si

Received/Prejeto: 11.05.2010 


\section{METHODLOGY}

Historic maps (Gallino 1924/28; Shaw 2006) and publications (R. R. Grotte demaniali di Postumia 1928, Perco \& Gradenigo 1930) were studied to find the position of Sala del Candore where a stalagmite column supposedly collapsed during $1^{\text {st }}$ January 1926 earthquake. Transla- tions from Italian (Zanon 1926, R. R. Grotte demaniali di Postumia 1928, Perco \& Gradenigo 1930) to English were done by the author. Personal communications related to felt earthquakes in karst caves were also collected as important field testimonies.

\section{RESULTS AND DISCUSSION}

\section{EFFECTS OF $1^{\text {st }}$ JANUARY 1926 EARTHQUAKE IN POSTOJNA CAVE SYSTEM}

During the strongest historical earthquake, which occurred on the territory of present-day Slovenia in 1511 (26 ${ }^{\text {th }}$ March), Postojna castle on Sovič Mountain was de- stroyed (Koblar 1895). About possible damage in Postojna cave system, which in that period was not known at its present length, there are no known sources.

The French karstologist Martel $(1894,446)$ wrote, that according to Schmidl (1854), the formation of cave collapses in Postojna cave system can be connected with

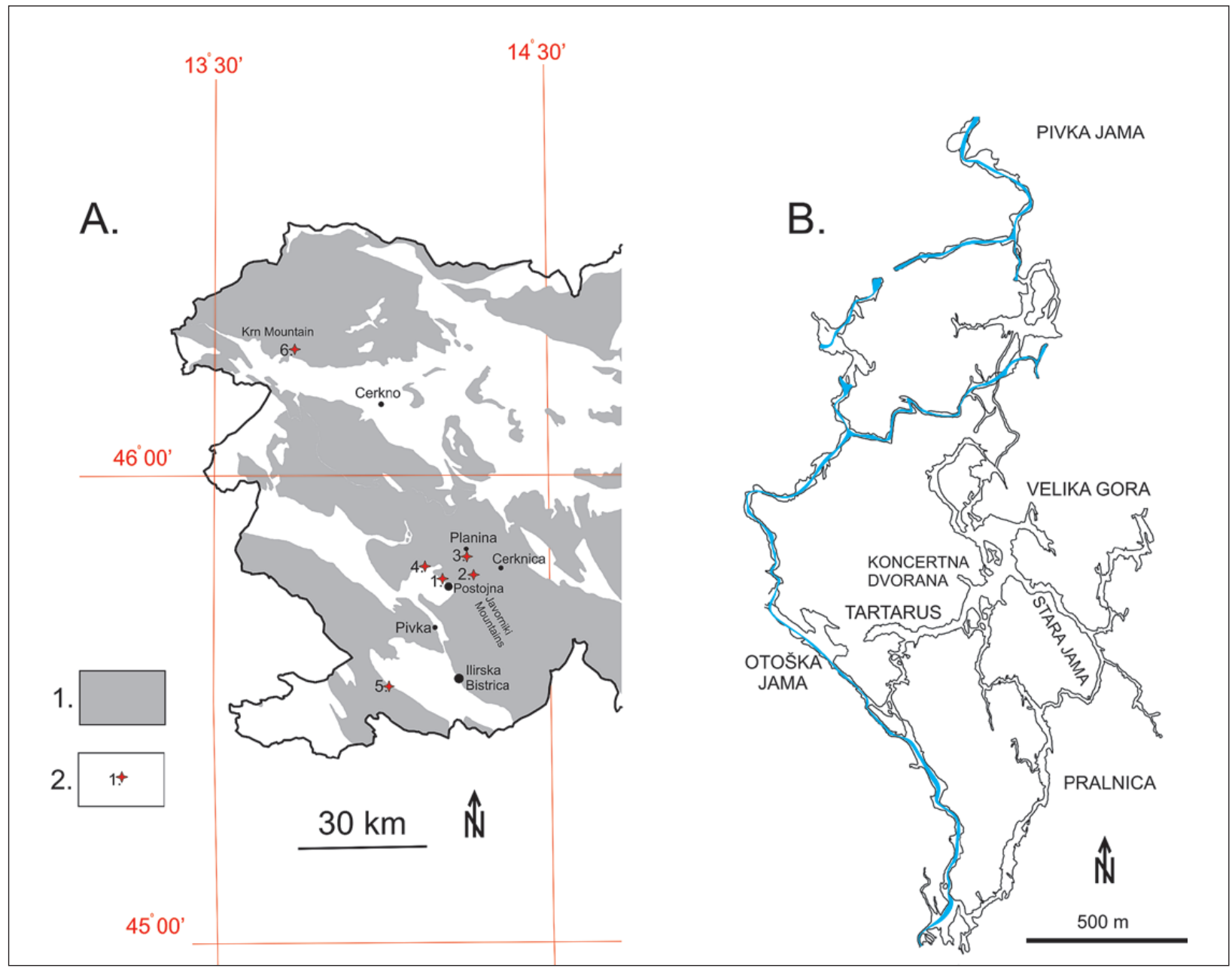

Fig. 1: A - Western Slovenia [1-karst area, 2-caves (1-Postojna cave system, 2-Zelše caves, 3-Planina cave, 4-Predjama cave system, 5-Dimnice caves, 6-Polog cave)], B - map of Postojna cave system. 
earthquakes. Schmidl (1854, 185-186) depicted the strongly felt earthquake in Postojna and Planina (Fig. 1) on $2^{\text {nd }}$ February 1834. According to Ribarič (1982) this magnitude 3.9 earthquake occurred in the vicinity of Postojna (Javorniki Mountain) and brontide was heard, that is sound like distant thunder, due to seismic causes. This is probably one of the oldest descriptions of an earthquake in the near vicinity of Postojna cave system.

The same earthquake from $2^{\text {nd }}$ February 1834 was described also by Koblar (1895). Two minutes after 9 o' clock in the morning a weak earthquake was felt in Planina, Postojna and Slavina. Shortly after the first earthquake the second stronger one occurred. Thundering and rumbling noise were heard. The direction was from north towards south.

Koblar (1895) has also mentioned the earthquakes on $14^{\text {th }}$ May 1858 and in 1872, both felt in Postojna.

In his annual report (Belar 1900), the Slovene seismologist Albin Belar (1864-1939), who in 1897 established the first seismological station on the territory of Slovenia, described a weak earthquake on 3rd April 1900 at 11:30 felt in Postojna cave. The same earthquake was not included in the earthquake catalogue of Ribarič (1982).

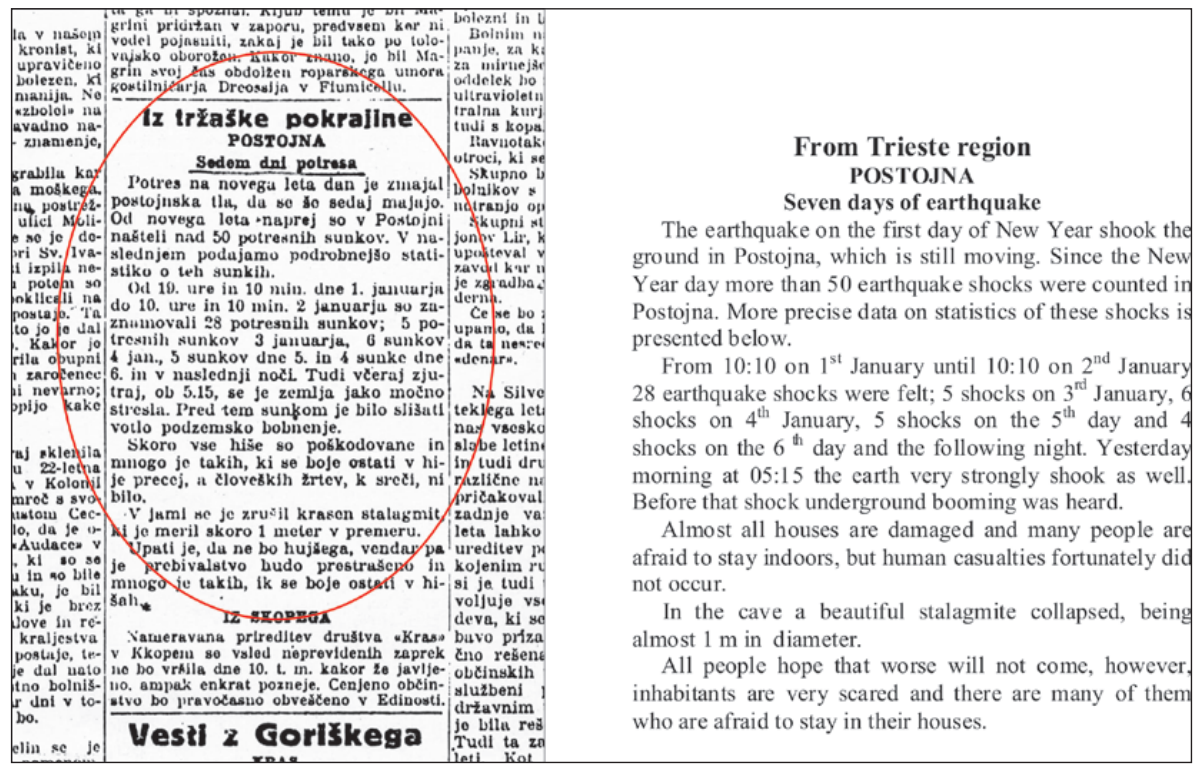

Fig. 2: The note on January 1926 earthquakes in Postojna in journal Edinost (Anonymous 1926) with English translation.

In Postojna cave system a strong earthquake was felt on $1^{\text {st }}$ January 1926 . This was the so-called Cerknica earthquake with magnitude $5.6\left(\mathrm{I}_{0}=8\right)$. Ribarič (1982) and Poljak et al. (2000) located the earthquake at the SE end of the Idrija Fault or at Javorniki Mountain. The newspaper Edinost (Anonymous 1926) from $8^{\text {th }}$ January about $17 \mathrm{~km}$.
1926 published that in Postojna cave a big stalagmite of almost $1 \mathrm{~m}$ in diameter collapsed due to the earthquake (Fig. 2). This is an interesting statement, because it is very rare that during the earthquakes big collapses occur in caves (Šebela 2008). According to Anonymous (1926) more than 50 earthquakes were felt in 7 days in Postojna and many houses were destroyed.

Another article from September 1926 (Zanon 1926) described the testimony of Ivan Andrej Perko, director of Postojna cave system in that period (1918-1945). According to Perko nothing collapsed inside the cave, but strong sounds like explosions or collapses accompanied earthquakes. These were the so-called brontides, which are sound phenomena of earthquakes. Brontides and lightning as earthquake phenomena were detected as far as Venice in Italy (Zanon 1926). Brontides are very typical for Javorniki-Snežnik-Pivka seismogenic area and are heard also nowadays during earthquakes.

Ivan Andrej Perko said that the earthquake on 1st January 1926 started at 19:05 and was 45 seconds long. Aftershocks were present for almost 20 days. Before several earthquakes strong sounds were heard. Inside the cave earthquakes and brontides were felt more strongly than outside, but no collapse or other similar changes were noticed in the cave. Andrej Perko had the impression that a huge underground cave collapsed in the area of Postojna (Zanon 1926).

Zanon (1926) described the earthquake from 1 st January 1926 as the Venice earthquake with epicentre near Postojna (Fig. 3). In L' Osservatorio geofisico del Seminario Patriarcale in Venice the earthquake was detected by two instruments. One was micro-seismograph Vicentini and another was a seismograph with horizontal pendulums called Agamennone. Zagreb observatory determined the epicentral area of the earthquake to be in Cerknica polje, but Zanon (1926) calculated Postojna as the epicentre. The estimated hypocentral depth was

In the annual report of Postojna cave administration (R. R. Grotte demaniali di Postumia 1928) for the period from 1st July 1926 to 31st December 1927, there is a record in Italian language on page 12: "Sgombro dei 


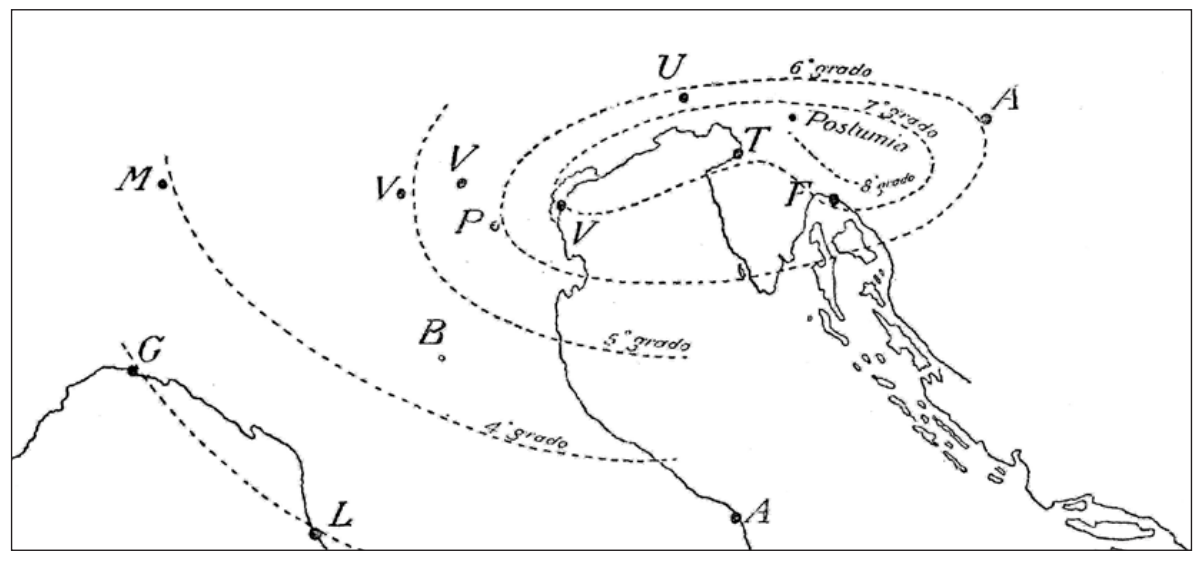

Fig. 3: Isoseismal lines of $1^{\text {st }}$ January 1926 earthquake (Zanon 1926).

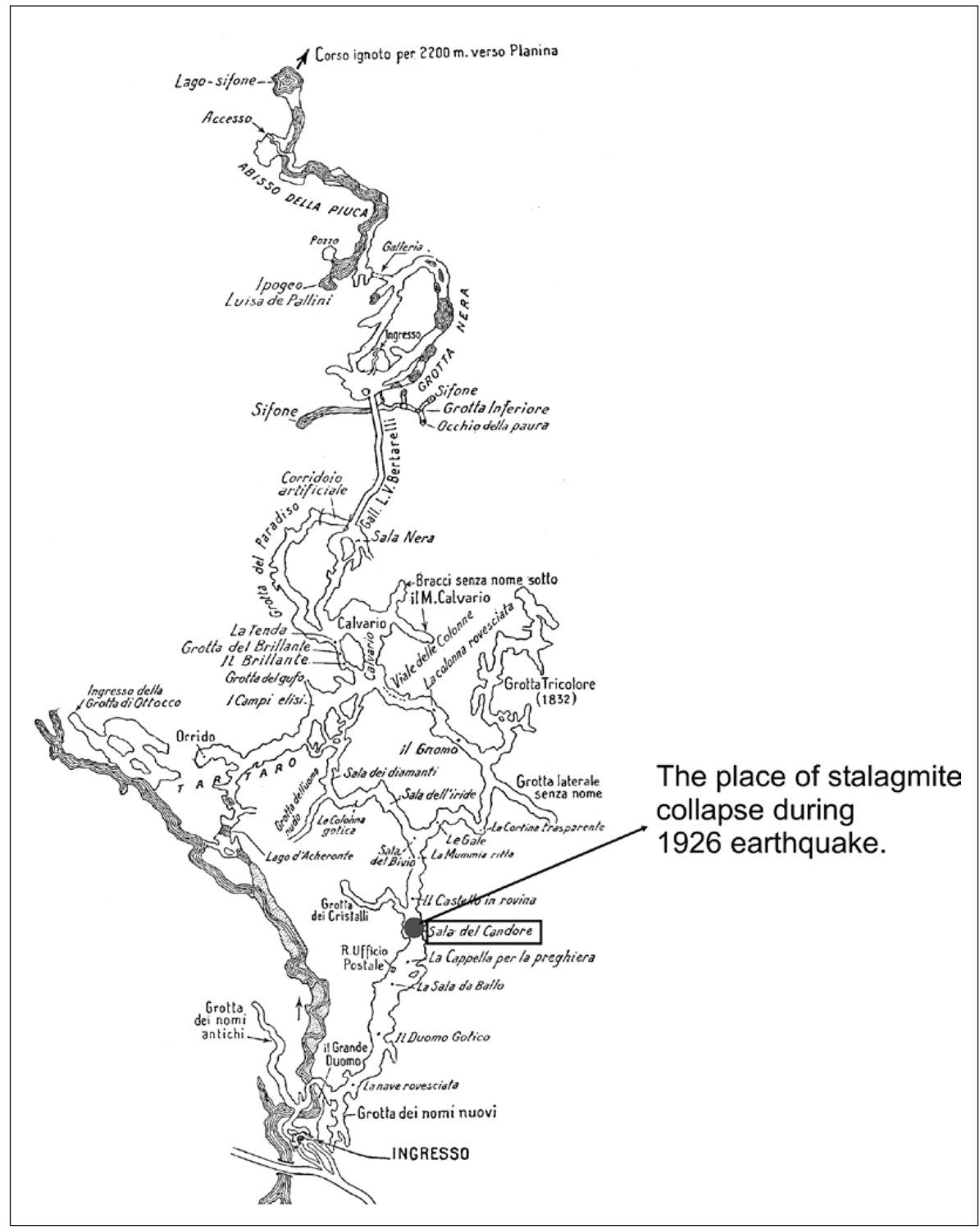

Fig. 4: The map of Postojna cave system (Perco \& Gradenigo 1930) with Sala del Candore where stalagmite collapsed due to the $1^{\text {st }}$ January 1926 earthquake. pezzi di una grande colonna rovesciatasi nella Scala del Candore in seguito al terremoto del giorno 1 gennaio 1926" (Removal of pieces of big column that collapsed in Scala del Candore as consequence of the earthquake on $1^{\text {st }}$ January 1926). This record confirms the news in Edinost newspaper (Anonymous 1926) and is contrary to the statement of Perko (Zanon 1926).

The position of Sala del Candore (or Scala del Candore) is marked on the map of 1930 (Fig. 4). Sala del Candore represents a big passage $24 \mathrm{~m}$ wide, $16 \mathrm{~m}$ high and $100 \mathrm{~m}$ long. At its northern end there is a flowstone called Razvaline Gradu. Regarding this description from Perco \& Gradenigo (1930) it looks that today this part of the cave is called Pralnica at its southern part (Figs. 5 and 6). The chamber is about 600 $m$ distant from the cave entrance. The collapsed stalagmite column was probably deposited over unstable cave sediments and the earthquake just added to its instability.

According to Perco \& Gradenigo (1930) the passage Sala del Candore is situated north from the passage Il Grande Ciondolo, which according to the photo in Perco \& Gradenigo (1930) corresponds to other names as Reisenquaste, Luster, Koruza (Fig. 7) described by Shaw (2006). Between Sala del Candore on the north and Il Grande Ciondolo on the south there is shorter passage with collapse blocks and white flowstone (Fig. 8). In our opinion this can as well 


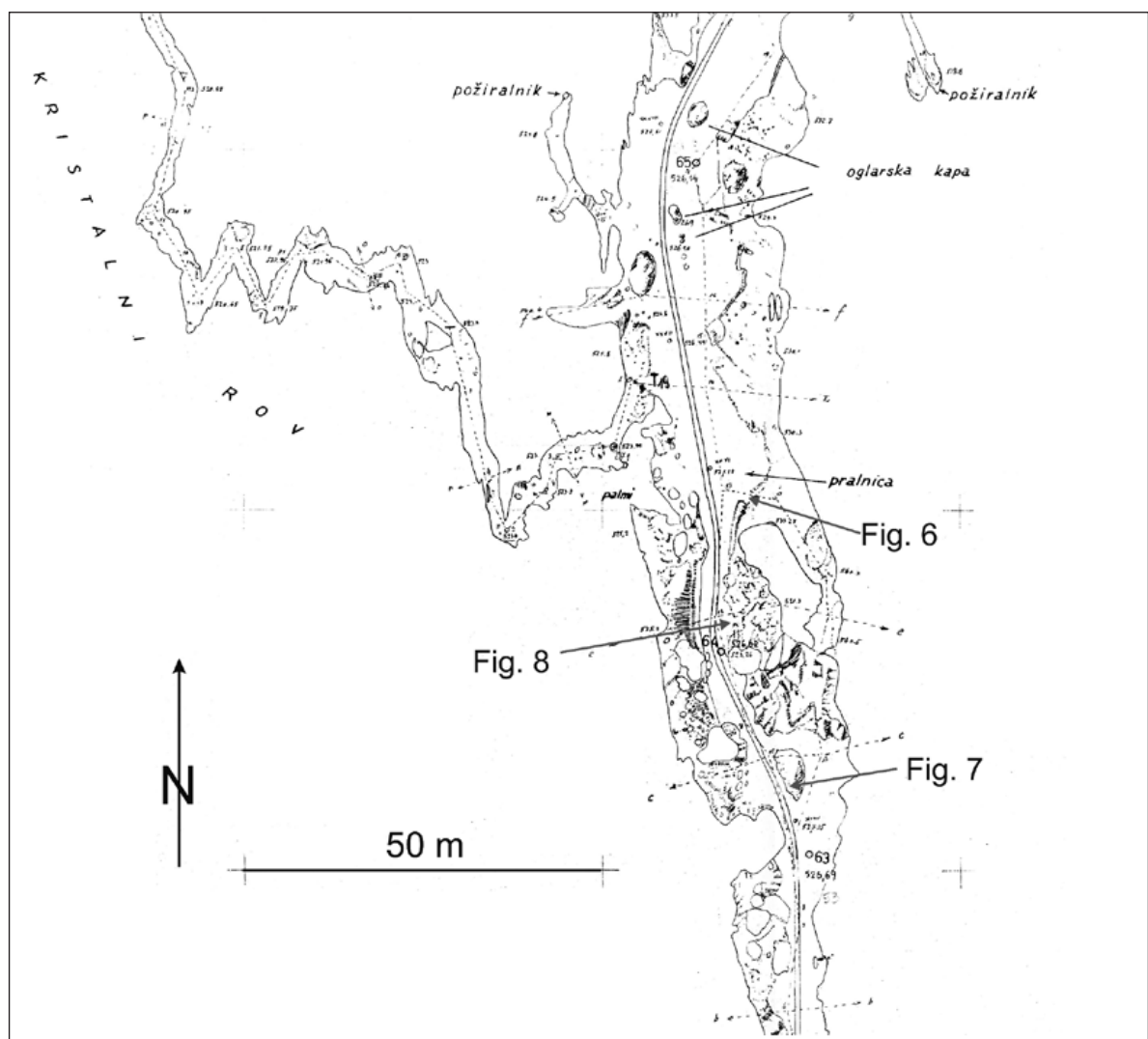

Fig. 5: The ground-plan (Gallino 1924/28) of the area where stalagmite collapsed due to the 1926 earthquake.

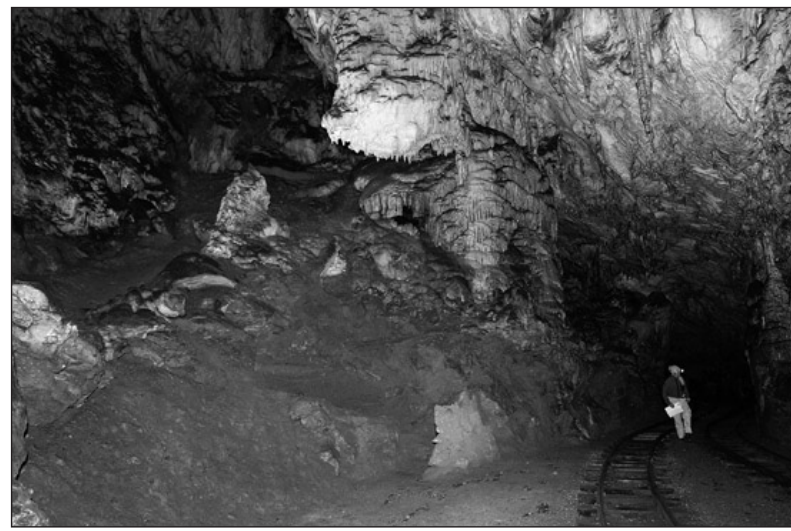

Fig. 6: Pralnica - the view towards south (Photo: S. Šebela).

be a good place for stalagmite collapse due to the earthquake.

The statement of Perko that there were no traces of collapse in the cave due to the earthquake (Zanon 1926), can be explained if he did not want to make negative publicity for eventual cave visitors or maybe he was not aware of the stalagmite collapse. Anyway two reports on column collapse in the cave (Anonymous 1926, R. R. Grotte demaniali di Postumia 1928), make it very pos- sible that a big stalagmite column with almost $1 \mathrm{~m}$ in diameter collapsed due to the 1926 earthquake.

\section{EFFECTS OF OTHER \\ EARTHQUAKES IN POSTOJNA CAVE SYSTEM}

During the magnitude 6.5 Friuli (NE Italy) earthquake on $6^{\text {th }}$ May 1976 in the Tartarus passage of Postojna cave system the glass plates fixed along the stalagmite crack (Figs. 9 and 10) are supposed to break. But according to personal communication of some cave guides the glass plates, which were cemented to see the stability or instability of the stalagmite base, were destroyed on purpose and not due to the earthquake.

The cave guide Benjamin Cah (personal communication 2010) felt the $12^{\text {th }}$

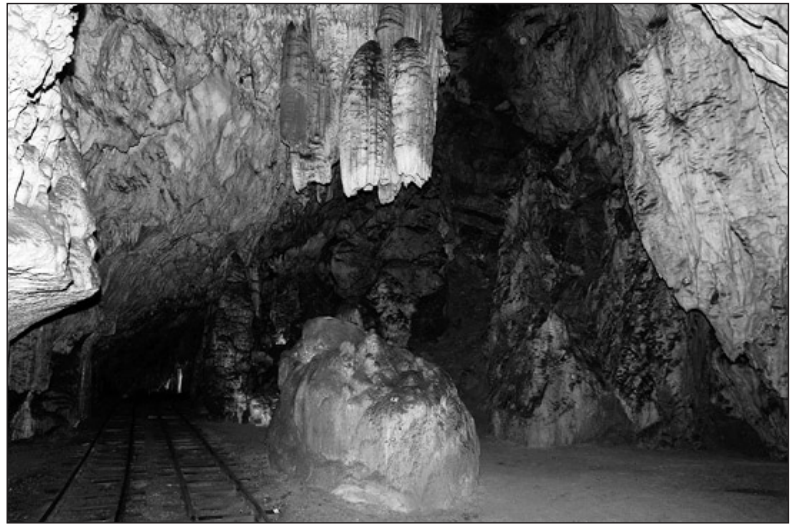

Fig. 7: The chamber with flowstone decorations from the ceiling called Il Grande Ciondolo, Reisenquiste, Luster, Koruza, the view towards north (Photo: S. Šebela).

April 1998 earthquake $\left(M_{w}=5.6\right.$, Krn Mountain $)$ in the cave while guiding group of tourists. He was walking and felt only modest ground shaking, but the brontide was very loud, as something exploded or as the train would be coming with great speed. Also the train driver Damjan König (personal communication 2010) heard strong noise, as booming, but did not feel any shaking due to the driving. 


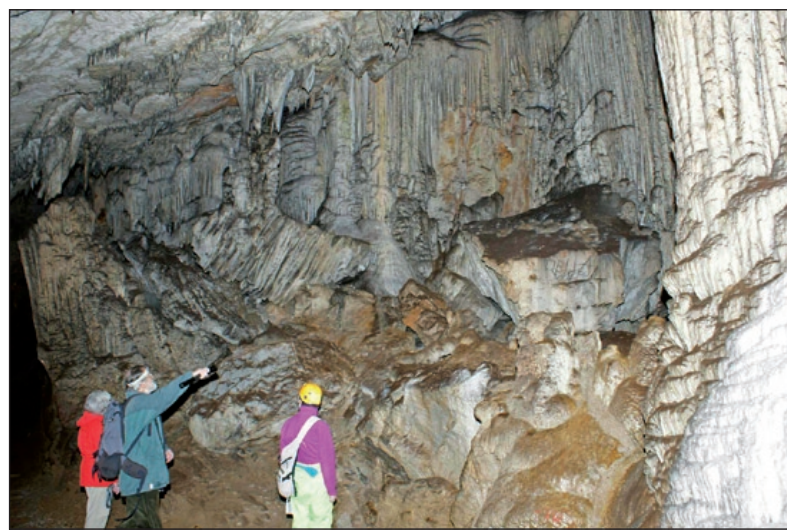

Fig. 8: The shorter passage between Sala del candore on the north and Il Grande Ciondolo, (Reisenquiste, Luster, Koruza) on the south, the view towards north (Photo: S. Šebela).

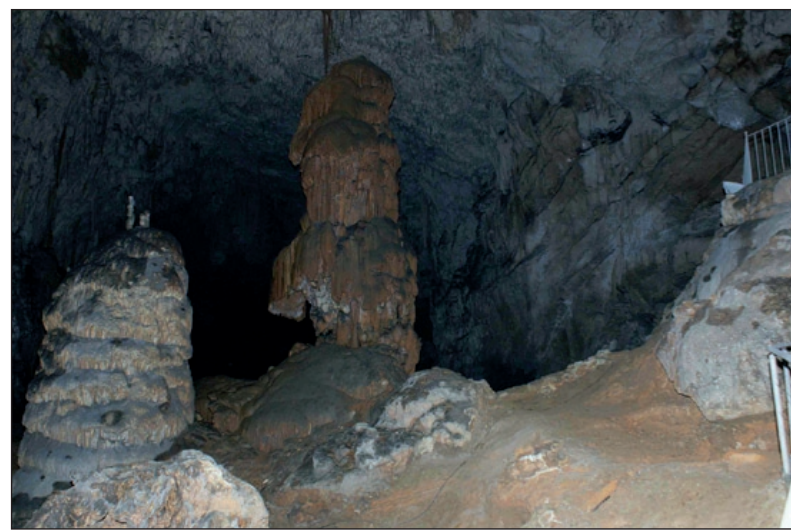

Fig. 9: Stalagmite in Tartarus (Photo: S. Šebela).

The Krn Mountain earthquake of $12^{\text {th }}$ July 2004 $\left(\mathrm{M}_{\mathrm{w}}=5.2\right)$ was felt in the Postojna cave system by cave guides. They heard a noise like a train coming down from the Velika Gora and going towards Koncertna Dvorana. They did not feel the earthquake shocks and did not hear any brontides or collapse in the cave (Glažar 2006).
On $14^{\text {th }}$ January 2005 two earthquakes occurred near Cerkno (at 8:58 $\mathrm{M}=4.0$ and at 9:05 $\mathrm{M}=3.8$ ). In Postojna cave system we (Stanka Šebela, Mélanie Duval and Janez Mulec) have been taking measurements from a TM 71 extensometer on Velika Gora from 10:25 to 11:05 local time on the same day. Around 11:00 o' clock we heard a noise like a train coming from Stara Jama towards Velika Gora. It was a brontide connected with a Cerkno aftershock.

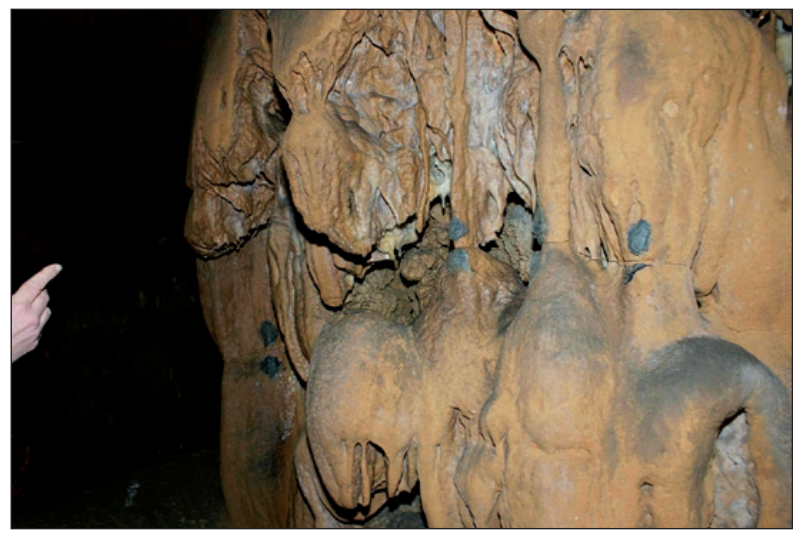

Fig. 10: The nearly horizontal crack on stalagmite in Tartarus (Photo: S. Šebela).

The guide in Postojna cave system Mojca Najzer (personal communication 2010) gave an interesting statement on the $15^{\text {th }}$ January 2010 earthquake $(M=3.7)$ in Postojna. It was 15:20 o' clock and she was guiding a group of tourists on Velika Gora. First they heard a strong detonation like rocks collapsing or a construction falling down, immediately after that the ground waved under foot. They did not feel the ground movement as shaking but as a wave. On Velika Gora they were walking on the concrete tourist path over collapse limestone blocks partly cemented with flowstone. During the same visit they heard three more brontides.

\section{CONCLUSIONS}

Regarding the studied historic sources (Anonymous 1926; Zanon 1926; R. R. Grotte demaniali di Postumia 1928) it looks that there are sufficient proofs that during the $1^{\text {st }}$ January 1926 earthquake $(M=5.6)$ in Postojna cave system (Sala del Candore or Pralnica, Figs. 5 and 6) a stalagmite column of $1 \mathrm{~m}$ in diameter collapsed. This is a not so common event in karst caves (Becker et al. 2005, 2006; Šebela 2008) and probably took place due to the close vicinity of the epicentre being located at the SE end of Idrija Fault or in the Javorniki Mountain (Ribarič 1981; Poljak et al. 2000).

From some Slovene caves we have testimonies of cavers who felt the earthquakes. Žumer (1996) described that, during the $22^{\text {nd }}$ May 1995 earthquakes ( $M=4.0$ and 4.2) in Ilirska Bistrica, in Dimnice cave a stronger wind flow, and a sound and splashing of water in the underground river were noticed. In Zelše caves during the same earthquake a fallen rock hit a flowstone column 
about $1.3 \mathrm{~m}$ high in Lekšan chamber and broke it off beneath the cave ceiling, causing the column to overturn (Drole personal communication 2010).

During the $21^{\text {st }}$ October 2008 Pivka earthquake (M=3.1) Malečkar (2010) was in Dimnice cave. He described the brontide, shaking of a concrete plate called the »dancing floor " in the cave, on which he was standing, and a noise of falling rock.

Cavers described the collapse of some limestone blocks that had already been unstable in Polog cave about $70 \mathrm{~m}$ deep into the cave from its lower entrance after the Krn Mountain earthquake of $12^{\text {th }}$ April 1998 (Fratnik personal communication 2008). But the collapse of some blocks in the cave can be connected to co-seismic rock- fall on the mountain in 1998 and not directly to earthquake shocks. It should be noted that the Polog cave is located in the immediate vicinity of seismogenic Ravne Fault (Kastelic et al. 2008) at which this earthquake occurred. During the same earthquake on $12^{\text {th }}$ April 1998 two cavers were in Planina cave and heard the sound of booming, but they did not feel any ground shaking (Pristavec 2010).

Earthquakes in karst caves are generally more usually heard (brontides) or as ground motions felt only strong earthquakes can be felt as ground shaking or waving inside the caves and there may be some possible collapses (Kostov 2002) as well.

\section{ACKNOWLEDGEMENTS}

The author is thankful to Ina Cecić (Office of Seismology and Geology of the Environmental Agency of the Republic of Slovenia) for the given information on Postojna earthquakes (Anonymous 1926; Belar 1900). Stanislav Glažar (TURIZEM KRAS, Destinacijski management, d.d.) found the report on earthquake from 1834 in Martel (1894). Leon Drame (ZRC SAZU Karst Research Institute) informed me about earthquake informations from Koblar (1895). Trevor R. Shaw (ZRC SAZU Karst Research Institute) and Alenka Čuk (Notranjska Museum, Postojna) provided the copy of the report on annual activity of Postojna cave (R. R. Grotte demaniali di Pos- tumia 1928). My thanks go to Mojca Najzer, Benjamin Cah and Damjan König for their testimonies, as well as to personal communications of Franjo Drole and Andrej Fratnik. Trevor R. Shaw significantly improved the original manuscript.

The study was performed within the projects Strokovni nadzor in svetovanje pri upravljanju $z$ jamskimi sistemi (Expert control and recommendations for management of cave systems) and Klimatski in biološki monitoring jamskih sistemov (Climatic and biologic monitoring of cave systems) financed by Turizem KRAS Destinacijski management d.d.

\section{REFERENCES}

Anonymous, 1926: Iz tržaške pokrajine, Postojna, sedem dni potresa.- Edinost, dne 8. januar 1926, Trst.

Becker, A., Ferry, M., Monecke, K., Schnellmann, M. \& D. Giardini, 2005: Multiarchive paleoseismic record of late Pleistocene and Holocene strong earthquakes in Switzerland.- Tectonophysics, 400, 153-177.

Becker, A., Davenport, C., Eichenberger, U., Gilli, E., Jeannin, P.-Y. \& C. Lacave, 2006: Speleoseismology: A critical perspective.- Journal of Seismology, 10, 3, 371-388.

Belar, A., 1900: Erdbeben im Monate April 1900.- Mittheilungen der Erdbebenwarte an der k.k. StaatsOberrealschule in Laibach, Pleinmahr \& Bamberg, 1614, Laibach.
Gallino, L., 1924/28: Tavole del Rilievo delle R.R. Grotte di Postumia. 1:500.- Postumia.

Glažar, S., 2006: Strela in potres v Postojnski jami.- Naše jame, 46, 118-119.

Gosar, A., Šebela, S., Košták, B. \& J. Stemberk, 2007: Micro-deformation monitoring of active tectonic structures in W Slovenia.- Acta Geodyn. Geomater., 4, 1, 87-98.

Gosar, A., Šebela, S., Košták, B. \& J. Stemberk, 2009: Surface versus underground measurements of active tectonic displacements detected with TM 71 extensiometers in Western Slovenia.- Acta Carsologica, $38,2-3,213-226$. 
Kastelic, V., Vrabec, M., Cunningham, D. \& A. Gosar, 2008: Neo-Alpine structural evolution and presentday tectonic activity of the eastern Southern Alps: The case of Ravne Fault, NW Slovenia.- Journal of Structural Geology, 30, 963-975.

Koblar, A., 1895: Zemeljski potresi na Slovenskem.- Izvestja muzejskega društva za Kranjsko, 5, 2, 68-77.

Kostov, K., 2002: Speleothems as paleoseismic indicators: examples from Bulgaria.- In: Leroy, S. \& I.S. Stewart (eds.) Environmental Catastrophes and Recovery in the Holocene, Brunel University, 28 August-2 September 2002, London (UK). Abstract Vol., 43-44, London.

Malečkar, F., 2010: Potres v Dimnicah.- [Online] Available from: http://franci-maleckar.blogspot.com [Accessed 24 ${ }^{\text {th }}$ February 2010].

Martel, E. A., 1894: Les abîmes.- Librarie Charles Delagrave, pp. 578, Paris.

Perco, G. A. \& S. Gradenigo, 1930: Postumia ed il fantastico mondo sotterraneo delle sue celebri grotte.Pubblicazione ufficiale della R. Amministrazione delle grotte di Postumia, pp. 204, Postumia.

Poljak, M., Živčić, M. \& P. Zupančič, 2000: The seismotectonic characteristics of Slovenia.- Pure and Applied Geophysics, 157, 37-55.

Pristavec, J., 2010: Potres v Planinski jami.- [Online] Available from: http://www.ljudmila.org/jkz/html/ body_novice_1.html) [Accessed 24 ${ }^{\text {th }}$ February 2010].

R. R. Grotte demaniali di Postumia, 1928: Relazione del consiglio d'amministrazione alle loro eccellenze i ministri dell'economia nazionale e delle finanze sull'andamento dell'azienda dal $1^{\circ}$ luglio 1926 al 31 dicembre 1927.- R. R. Grotte demaniali di Postumia, 6, pp. 57, Postumia.

Ribarič, V., 1982: Seismicity of Slovenia - Catalogue of Earthquakes (792 A.D. - 1981).- SZ SRS Publication, A, 1-1, pp. 650, Ljubljana.

Schmidl, A., 1854: Die Grotten und Höhlen von Adelsberg, Lueg, Planina und Laas.- Akademie der Wissenschaften, V-VIII, pp. 3-314, Wien.

Shaw, T., 2006: Names from the past in Postojnska jama (Postojna Cave).- Založba ZRC, pp. 151, Ljubljana.
Šebela, S., 2005: Monitoring of active tectonic structures - Project COST 625.- Acta carsologica, 34, 2, 471488.

Šebela, S., 2008: Broken speleothems as indicators of tectonic movements.- Acta carsologica, 37, 1, 51-62.

Šebela, S., 2010: O podrtem kapniku ob Cerkniškem potresu (1926) ter o raziskovalni postaji s horizontalnimi nihali v Postojnski jami.- In: Kuhar, M. (ed.) Razprave s področja geodezije in geofizike 2009, 15. strokovno srečanje Slovenskega združenja za geodezijo in geofiziko, 21. januar 2010, Ljubljana. Univerza v Ljubljani, Fakulteta za gradbeništvo in geodezijo, 17-22, Ljubljana.

Šebela, S. \& A. Gosar, 2005: Začetek meritev premikov ob prelomih v zahodni Sloveniji s 3D estenziometri TM 71.- In: Kozmus, K. \& M. Kuhar (eds.) Raziskave s področja geodezije in geofizike, 10. strokovno srečanje Slovenskega združenja za geodezijo in geofiziko, 13. januar 2005, Ljubljana. Univerza v Ljubljani, Fakulteta za gradbeništvo in geodezijo, 37-45, Ljubljana.

Šebela, S., Gosar, A., Košták, B. \& J. Stemberk, 2005: Active tectonic structures in the W part of Slovenia - Setting of micro-deformation monitoring net.Acta Geodyn. Geomater., 2, 1, 45-57.

Šebela, S., Košták, B., Mulec, J. \& J. Stemberk, 2008: Merjenje tektonskih premikov v Postojnski jami.- In: Kuhar, M. (ed.) Raziskave s področja geodezije in geofizike 2007, 13. strokovno srečanje SZGG, 17. januar 2008, Ljubljana. Univerza v Ljubljani, Fakulteta za gradbeništvo in geodezijo, 21-26, Ljubljana.

Šebela, S., Turk, J., Mulec, J., Košták, B. \& J. Stemberk, 2009: Statistical evaluation of the 3D monitoring of displacements of Dinaric Fault Zone in Postojna Cave, Slovenia.- Acta Geodyn. Geomater., 6, 2, 163-176.

Zanon, S., 1926: Il terremoto di Venezia del $1^{\circ}$ gennaio 1926.- Rivista mensile della citta di Venezia, 5, 9, 383-392.

Žumer, J., 1996: Potres v Dimnicah.- Naše jame, 38 (1997), 152-154. 